\title{
Supramolecular Structure and Functional Analysis of the Type III Secretion System in Pseudomonas fluorescens 2P24
}

\author{
Ping Liu ${ }^{1}$, Wei Zhang ${ }^{2,3}$, Li-Qun Zhang ${ }^{2}$, Xingzhong Liu' ${ }^{1}$ and Hai-Lei Wei ${ }^{1 *}$ \\ ${ }^{1}$ State Key Laboratory of Mycology, Institute of Microbiology, Chinese Academy of Sciences, Beijing, China, ${ }^{2}$ Department of \\ Plant Pathology, China Agricultural University, Beijing, China, ${ }^{3}$ MOE Key Laboratory of Regional Energy and Environmental \\ Systems Optimization, Resources and Environmental Research Academy, North China Electric Power University, Beijing, \\ China
}

The type III secretion system (T3SS) of plant and animal bacterial pathogens directs the secretion and injection of proteins into host cells. Some homologous genes of T3SS were found also in non-pathogenic bacteria, but the organization of its machinery and basic function are still unknown. In this study, we identified a T3SS gene cluster from the plant growth-promoting Pseudomonas fluorescens 2P24 and isolated the corresponding T3SS apparatus. The T3SS gene cluster of strain 2P24 is similar

OPEN ACCESS

Edited by:

Teresa Rebecca De Kievit, University of Manitoba, Canada

Reviewed by:

Nai-Chun Lin National Taiwan University, Taiwan Lei Zhang,

Washington State University, USA

*Correspondence: Hai-Lei Wei weih@@im.ac.cn

Specialty section: This article was submitted to Plant Biotic Interactions, a section of the journal Frontiers in Plant Science

Received: 13 September 2015 Accepted: 11 December 2015 Published: 05 January 2016

Citation:

Liu P, Zhang W, Zhang L-Q, Liu X and Wei H-L (2016) Supramolecular

Structure and Functional Analysis of the Type III Secretion System in Pseudomonas fluorescens 2P24.

Front. Plant Sci. 6:1190 doi: 10.3389/fpls.2015.01190 organizationally to that of pathogenic $P$. syringae, except that it lacks the regulator $h r p R$ and the $h r p K 1$ and $h r p H$ genes, which are involved in translocation of proteins. Electron microscopy revealed that the T3SS supramolecular structure of strain 2P24 was comprised of two distinctive substructures: a long extracellular, filamentous pilus, and a membrane-embedded base. We show that strain 2P24 deploys a harpin homolog protein, RspZ1, to elicit a hypersensitive response when infiltrated into Nicotiana tabacum cv. xanthi leaves with protein that is partially purified, and by complementing the hrpZ1 mutation of pHIR11. The T3SS of strain 2P24 retained ability to secrete effectors, whereas its effector translocation activity appeared to be excessively lost. Mutation of the rscC gene from 2P24 T3SS abolished the secretion of effectors, but the general biocontrol properties were unaffected. Remarkably, strain 2P24 induced functional MAMP-triggered immunity that included a burst of reactive oxygen species, strong suppression of challenge cell death, and disease expansion, while it was not associated with the secretion functional T3SS.

Keywords: type III secretion system, PGPR, harpin, MTI, Pseudomonas fluorescens

\section{INTRODUCTION}

In natural systems, plants are attacked continuously by a broad spectrum of pathogens and, at the same time, they are protected by a large number of beneficial microorganisms. For plant pathogenic bacteria such as Pseudomonas, Erwinia, Xanthomonas, and Ralstonia, non-flagellar type III secretion system (T3SS) is deployed to secrete and deliver repertoires of effector proteins to suppress innate immunity and cause diseases (Mansfield et al., 2012). The T3SS apparatus, which 
is referred to as a needle complex, is comprised of three functional modules: (i) a cylindrical basal body that spans the bacterial inner and outer membranes with a presumed central rod to build a channel, (ii) a needle/pilus structure that extrudes from the bacterial outer membrane and functions as a conduit for effector transfer, and (iii) a translocon complex that produces a pore in the host plasma membrane to inject the effectors (Galán and Collmer, 1999; Wei and Collmer, 2012). In recent years, a large variety of structural studies on animal and human bacterial T3SS was conducted. Parts of the system have been described at molecular resolution (Deane et al., 2006; Moraes et al., 2008; Spreter et al., 2009; Schraidt and Marlovits, 2011; Fujii et al., 2012; Bergeron et al., 2013), but few plant-associated bacterial T3SS have been studied, and most of these studies have been in P. syringae (Roine et al., 1997; Hu et al., 2001; Jin et al., 2001; Li et al., 2002). In Pseudomonas syringae pv. tomato DC3000, a pilus is comprised of a major subunit of the T3SS, the HrpA1 protein, which extends to the plant cell (Roine et al., 1997). This pilus is flexible and its length of $\sim 2 \mu \mathrm{m}$ is much greater than that of the needles found in animal pathogens (Roine et al., 1997). An in situ immunogold labeling was used to visualize the extrusion of the effector and harpin proteins from the tip of the Hrp pilus, which demonstrates that the bacterial pilus can function as a conduit for protein delivery (Jin et al., 2001; Li et al., 2002).

Pseudomonads, which are distributed widely in many natural niches, are an environmentally significant group of bacteria that includes both pathogenic and saprophytic species. Among the pathogenic fluorescent pseudomonads, the importance of the T3SS and its effectors has been well-studied in the opportunistic human and animal pathogen P. aeruginosa (Hauser, 2009) and the plant pathogen $P$. syringae (Alfano and Collmer, 2004; Xin and He, 2013). However, in the last 15 years the presence of a T3SS is continuously being reported in a few plant growth-promoting pseudomonads with partial and whole genome sequencing (Preston et al., 2001; Mazurier et al., 2004; Rezzonico et al., 2004, 2005; Mavrodi et al., 2011; Viollet et al., 2011; Barret et al., 2013; Duan et al., 2013; Berendsen et al., 2015). But unlike the plant pathogenic T3SS, the distribution and structure of the plant growth-promoting T3SS are not conserved highly, which results in a poor understanding of its function. For instance, a 20-kb type III gene cluster ( $r s p / r s c)$ that resembles the $h r p / h r c$ locus of $P$. syringae was identified initially in the sugar beet isolate, $P$. fluorescens SBW25, which lacks the harpinencoding gene, $h r p Z 1$, but elicits a hypersensitive response (HR)like cell death in Nicotiana clevelandii (Preston et al., 2001). In Q8r1-96, which is another well-studied P. fluorescens strain, a gene-encoding putative harpin-like protein (RspZ) was identified from the T3SS gene cluster, and the overall arrangement of the $r s p / r s c$ genes in Q8r1-96 differed from that in P. fluorescens SBW25 (Mavrodi et al., 2011). A phylogenic analysis of biocontrol Pseudomonas strains based on partial $h r c N$ sequences addressed the issue that horizontal gene transfer of the T3SS might take place from pathogenic bacteria to PGPR and that the T3SS apparatus may be maladaptive evolutionarily in some PGPR (Rezzonico et al., 2004). To date, no single T3SS machinery has been isolated from plant growth-promoting rhizobacteria (PGPR).
Pseudomonas fluorescens 2P24 is a PGPR strain isolated from wheat take-all decline soil in Shandong Province, China (Wei et al., 2004a). This strain produces several secondary metabolites, such as 2,4-diacetylphloroglucinol (2,4-DAPG), hydrogen cyanide ( $\mathrm{HCN})$, and siderophore(s), and it inhibits growth of a range of phytopathogenic fungi (Wei et al., 2004a). The antibiotic 2,4-DAPG was a key determinant in the antibiosis of plant pathogens (Wei et al., 2004b). In addition, strain 2P24 has excellent colonization ability in tomato and cotton rhizospheres to protect against tomato bacterial wilt and cotton rhizoctoniosis, respectively (Wei et al., 2004a). The biocontrol activity of strain 2P24 is regulated by the GacA/GacS two-component system and the quorum sensing regulation system (Wei and Zhang, 2005, 2006). In this work, we report the existence and organization of the T3SS cluster and characterization of a functional harpin-like protein in strain 2P24, and we isolate the T3SS machinery from $P$. fluorescens for the first time. Finally, we demonstrate that strain $2 \mathrm{P} 24$ induces strong MAMP-triggered Immunity (MTI), which is not associated with the T3SS.

\section{MATERIALS AND METHODS}

\section{Bacterial Strains, Plasmids, and Plant Material}

Escherichia coli strains were grown in Luria-Bertani (LB) broth at $37^{\circ} \mathrm{C}$. P. fluorescens and P. syringae were grown in King's medium B (KB) broth (King et al., 1954) at $28^{\circ} \mathrm{C}$. Construction of the cosmid library in E. coli DH5a was described in Wei and Zhang (2006). A summary of bacterial strains and plasmids is provided in Table 1. Antibiotics were used at the following concentrations unless otherwise stated ( $\mu \mathrm{g} / \mathrm{ml})$ : ampicillin, 100; gentamicin, 20; kanamycin, 50; rifampicin, 50; spectinomycin, 50; and tetracycline, 20. Nicotiana benthamiana and tobacco (N. tabacum cv. xanthi) plants were grown in a greenhouse with $16 \mathrm{~h}$ light $/ 8 \mathrm{~h}$ dark, $65 \%$ humidity, and a temperature of $24^{\circ} \mathrm{C}$ during daylight and $22^{\circ} \mathrm{C}$ at night.

\section{DNA Manipulations}

Recombinant DNA techniques were performed according to standard protocols (Sambrook et al., 1989). Electroporation was performed using a Bio-Rad GenePulser according to the manufacturer's protocol (Bio-Rad). Triparental mating was carried out using helper plasmid E. coli HB101 (pRK2013) according to the standard protocol. Plasmid DNA preparation and DNA gel extraction were done using the QIAprep Spin Miniprep Kit and QIAquick Gel Extraction Kit, respectively (Qiagen, China). Gateway recombination was conducted with LR clonase II, as recommended by the manufacturer (Invitrogen, China). DNA sequences of pN11-7, pN13-41, and pN31-20 were subcloned into pBluescript using EcoR I, Hind III, and Kpn I. Subclones were mapped, and selected subclones were sequenced using T3 and T7 primers. Additional sequences were obtained from subclones using specific oligonucleotide primers. All DNA sequencing was done at Invitrogen China. DNA sequences were assembled and analyzed with the sequence analysis software package of the Genetics Computer Group. 
TABLE 1 | Bacterial strains and plasmids used in this study.

\begin{tabular}{|c|c|c|}
\hline Strain or plasmid & Genotype or relative phenotype & Source \\
\hline $\mathrm{DH} 5 \alpha$ & 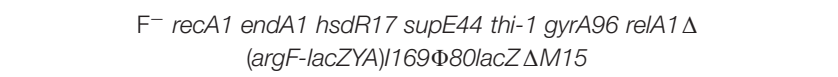 & Sambrook et al., 1989 \\
\hline \multicolumn{3}{|c|}{ Pseudomonas fluorescens } \\
\hline 2P24 & Plant growth-promoting bacterium & Wei et al., 2004a \\
\hline$\Delta \mathrm{C}$ & rscC deletion mutant & This study \\
\hline$\Delta$ flic & fliC insertion mutant & This study \\
\hline PfO-1 & Non-T3SS bacterium & Compeau et al., 1988 \\
\hline \multicolumn{3}{|l|}{ P. syringae } \\
\hline DC3000 & Wild type; Rifr & Buell et al., 2003 \\
\hline$\Delta$ hopQ1 & hopQ1 deletion mutant of strain DC3000 & Wei et al., 2007 \\
\hline \multicolumn{3}{|l|}{ plasmids } \\
\hline pENTR/SD-TOPO & Entry vector for Gateway cloning; $\mathrm{Km}^{r}, \mathrm{Cm}^{\mathrm{r}}$ & Invitrogen \\
\hline $\mathrm{pET}-22 \mathrm{~b}(+)$ & Expression vector; $A p^{r}$ & Novagen \\
\hline pLAFR5 & or $\mathrm{T}$ cosmid; $\mathrm{Tc}^{r}$ & Keen et al., 1988 \\
\hline pN11-7 & rsp genes positive cosmid clone & This study \\
\hline pN13-41 & rsp genes positive cosmid clone & This study \\
\hline pN31-20 & rsp genes positive cosmid clone & This study \\
\hline pBS11-7a & pBluescript containing $1.5 \mathrm{~kb}$ Hind III fragment from pN11-7 & This study \\
\hline pBS11-7b & pBluescript containing $5.8 \mathrm{~kb} E \mathrm{coR}$ I fragment from pN11-7 & This study \\
\hline pBS11-7c & pBluescript containing $6.4 \mathrm{~kb} E \mathrm{coR}$ I fragment from $\mathrm{pN} 11-7$ & This study \\
\hline pBS31-20b & pBluescript containing $4.1 \mathrm{~kb}$ EcoR I fragment from pN31-20 & This study \\
\hline pBS31-20a & pBluescript containing $6.6 \mathrm{~kb} K \mathrm{kn}$ I fragment from pN31-20 & This study \\
\hline рCPP2274 & pHIR11 containing an unmarked deletion $h r p Z 1$ & Gopalan et al., 1996 \\
\hline pCPP5371 & $\begin{array}{l}\text { pBBR1MCS containing avrPto } 1 \text { promoter, Gateway reading frame B cassette, } \\
\text { and codons } 2 \text { to } 406 \text { of cya; } \mathrm{Gm}^{r}, \mathrm{Cm}^{r}\end{array}$ & Oh et al., 2007 \\
\hline pCPP5372 & $\begin{array}{l}\text { pBBR1MCS containing avrPto1 promoter, Gateway reading frame B cassette, } \\
\text { and C-terminal } \mathrm{HA} \text { tag; } \mathrm{Gm}^{r}, \mathrm{Cm}^{r}\end{array}$ & Oh et al., 2007 \\
\hline pEN-rspZ1 & pENTR/SD-TOPO containing full length of rspZ1 without stop codon & This study \\
\hline pET22-rspZ1 & pET22b expressing $r s p Z 1$ & This study \\
\hline pET22-hrpZ1 & pET22b expressing hrpZ1 DC3000 & This study \\
\hline p5372-rspZ1 & pCPP5372 expressing rspZ1 & This study \\
\hline p5371-hopQ1 & pCPP5371 expressing hopQ1 & This study \\
\hline p5372-hopQ1 & pCPP5372 expressing hopQ1 & This study \\
\hline
\end{tabular}

DNA sequences were deposited in GenBank under the accession number KT582783.

\section{Construction of the flic, rspZ1, and rscC Mutants}

To make a fliC mutant of $P$. fluorescens $2 \mathrm{P} 24$, a $0.5-\mathrm{kb}$ fragment of $f l i C$ gene was amplified by PCR using primers P141 (5'-GCCGGCCTGCAAATCGCTACC-3') and P655
(5'-ACCTCTACCACGACCAGTCTGC-3') cloned into the SmaI site of pHSG299. The resulting pHSG299 derivative was transformed into $P$. fluorescens $2 \mathrm{P} 24$ to produce $2 \mathrm{P} 24 \Delta f l i C$ with kanamycin resistance. The fliC mutant was confirmed by the swimming mobility test on $\mathrm{KB}$ medium containing $0.3 \%$ agar. The rspZ1 mutation of $2 \mathrm{P} 24$ was made using a similar procedure as described above after a 0.5-kb fragment of rspZ1 gene was amplified using primers 
P181 (5'- GGTTCGACGGGCGGACAGTCTC - $\left.3^{\prime}\right)$ and P681 (5'-GCGCGCCGGGTGCTGGTCCAT- $\left.3^{\prime}\right)$. To delete the $r s c C$ gene from strain $2 \mathrm{P} 24$, two $1.1-\mathrm{kb}$ fragments carrying the left and right flanking regions of $r s c C$ were amplified by PCR using primer pair P2658 (5'-CCGCCCATGAATTCCGCCG-3') and P3740 (5'-GGTACGGGATCCGCGGACAC-3') and primer pair P4332 (5'-TCGGGATCCACCGCACGCAAC-3') and P5548 (5'-CGGCTGCAGGCATCGCCCTG-3'), respectively. Each fragment of the left and right regions was digested with relative restriction enzymes and was cloned into the EcoRI and PstI sites of pHSG299. The resulting pHSG299 derivative was transformed into $P$. fluorescens $2 \mathrm{P} 24$. The kanamycin resistance colonies were cured of pHSG299. The final kanamycin-sensitive mutants were screened by PCR.

\section{Isolation of Type III Secretion Machinery from $P$. fluorescens 2P24}

The methods used for P. syringae (Roine et al., 1997; Jin and $\mathrm{He}, 2001$ ) and Salmonella (Kubori et al., 1998) were modified to isolate the $P$. fluorescens type III secretion machinery. Briefly, a $2 \mathrm{ml}$ aliquot of overnight culture was inoculated into $200 \mathrm{ml} \mathrm{KB}$ liquid media, and the bacteria were grown until $\mathrm{OD}_{600} 0.8$. The bacteria collected by centrifugation were suspended in $20 \mathrm{ml}$ of $0.5 \mathrm{M}$ ice-cold sucrose solution containing $0.15 \mathrm{M}$ Tris, $10 \mathrm{mM}$ EDTA ( $\mathrm{pH} 8.0$ ), and $1 \mathrm{mg} / \mathrm{ml}$ lysozyme, followed by incubation for $1 \mathrm{~h}$ at $4^{\circ} \mathrm{C}$. The resulting spheroplasts were lysed by addition of $30 \%$ Triton $\mathrm{X}-100$ to the final concentration at $0.1 \%$ and incubated for $2 \mathrm{~h}$ at $4^{\circ} \mathrm{C}$. Then, we added $2.3 \mathrm{ml} 100 \mathrm{mM} \mathrm{MgSO}_{4}$ and centrifuged at $8000 \mathrm{r} / \mathrm{min}$ for $20 \mathrm{~min}$. The supernatant was transferred to a new tube and adjusted to $\mathrm{pH} 11$ with $1 \mathrm{M} \mathrm{NaOH}$, followed by incubation at $4^{\circ} \mathrm{C}$. To collect type III complexes, the lysate was subjected to ultracentrifugation at $22000 \mathrm{r} / \mathrm{min}$ for $1 \mathrm{~h}$ at $4^{\circ} \mathrm{C}$. The pellet was then suspended in $20 \mathrm{ml}$ buffer with $0.1 \mathrm{M} \mathrm{KCl-KOH} \mathrm{(pH} \mathrm{11.0),} 0.5 \mathrm{M}$ sucrose, and $0.1 \%$ Triton $\mathrm{X}-100$, and centrifuged at $22000 \mathrm{r} / \mathrm{min}$ for $1 \mathrm{~h}$ at $4^{\circ} \mathrm{C}$. We discarded the supernatant and added $15 \mathrm{ml}$ buffer with $10 \mathrm{mM}$ Tris- $\mathrm{HCl}$ (pH 8.0), $5 \mathrm{mM}$ EDTA, $0.1 \%$ Triton X-100, and then fractionated with $30 \%(\mathrm{w} / \mathrm{v}) \mathrm{CsCl}$ density gradient centrifugation at $22000 \mathrm{r} / \mathrm{min}$ for $2 \mathrm{~h} 4^{\circ} \mathrm{C}$. The pelleted type III secretion complexes were suspended in a small amount of buffer and examined immediately using a JEOL JEM-1400 Transmission Electron Microscope (TEM).

\section{Expression and Purification of Harpins}

For the expression and purification of soluble harpins, the $h r p Z 1_{\mathrm{DC} 3000}$ and $r s p Z 1$ genes lacking stop codons were cloned into $\mathrm{pET}-22 \mathrm{~b}$ expression vector, respectively. Derivative pET22b plasmids produce $\mathrm{C}$-terminal fusions with the $\mathrm{His}_{6}$ affinity tag. pET-22b plasmids were transformed into E. coli BL21(DE3). The expression process was described in a previous report with a slight modification (Kvitko et al., 2007). Single colonies of the expression strains were inoculated into $10 \mathrm{ml} \mathrm{LB}$ containing ampicillin and incubated for $12 \mathrm{~h}$ with shaking at $37^{\circ} \mathrm{C}$. The starter cultures were used to inoculate $100 \mathrm{ml}$ LB-carbenicillin cultures in flasks, which were incubated with shaking at $30^{\circ} \mathrm{C}$ to an optical density at $600 \mathrm{~nm}$ of ca.
0.4. IPTG was added to a final concentration of $1 \mathrm{mM}$, and the cultures were allowed to incubate for an additional $6 \mathrm{~h}$. Cell pellets were harvested and lysed according to the Qiagen protocol. The suspension was sonicated on ice with a Fisher Scientific 550 sonic Dismembrator. Cleared lysates were harvested at $12,000 \mathrm{rpm}$ for $30 \mathrm{~min}$ at $4^{\circ} \mathrm{C}$ and purified with Ninitrilotriacetic acid (NTA) agarose (QIAGEN). Purified harpins were stored at $4^{\circ} \mathrm{C}$ until use. Proteins were visualized by sodium dodecyl sulfate-polyacrylamide gel electrophoresis (SDS-PAGE), followed by staining with Coomassie brilliant blue. Protein concentrations were determined by the Bradford assay. Harpin preparations were diluted for plant reaction assays. Emptyvector preparations were obtained in parallel with each harpin preparation.

\section{Western Blot and CyaA Translocation Reporter Assays}

HopQ1 protein in cell and supernatant fractions were analyzed essentially as described by Kvitko et al. (2007). Samples were separated by electrophoresis on SDS-PAGE and analyzed by immunoblotting using primary anti-HA mouse monoclonal immunoglobulin G (IgG) antibodies and secondary anti-mouse IgG alkaline phosphatase conjugate antibodies, as described by Kvitko et al. (2007). An adenylate cyclase (CyaA) injection assay was used to test HopQ1 translocation (Kvitko et al., 2007). This assay can determine if a type III effector-CyaA fusion is injected into eukaryotic cells, because the CyaA enzyme is dependent on calmodulin, a protein present in sufficient amounts only inside eukaryotic cells. When a CyaA fusion is injected into plant cells, there is a substantial increase in cAMP, a product of the CyaA-catalyzed reaction. The fresh bacterial cells in $10 \mathrm{mM} \mathrm{MgCl} 2$ were infiltrated on $N$. benthamiana leaves at $10^{8} \mathrm{cfu} / \mathrm{ml}$. The leaf disks were collected at $12 \mathrm{~h}$ with a $1.0-\mathrm{cm}$-diameter cork borer. The cyclic AMP (cAMP) levels were determined by using a Correlate-EIA cAMP immunoassay kit according to the manufacturer's instructions (Enzo, USA).

\section{Phenotypic Characterization of the rscC Mutant}

The $r s c C$ mutant was compared to the parental strain $2 \mathrm{P} 24$ for production of the antibiotic 2,4-DAPG, HCN, exoprotease, and siderophores, as described previously (Wei et al., 2004a; Wei and Zhang, 2006). Antibiosis detections of strain 2P24 and the $r s c C$ mutant were performed on a PDA plate with Rhizoctonia solani and Ralstonia solanacearum as target pathogens. Plant protection experiments against tomato bacterial wilt were carried out in a greenhouse according to the method of Wei et al. (2004a).

\section{Assay for Reactive Oxygen Species (ROS)}

For ROS measurements, $N$. benthamiana leaf tissue was inoculated with bacterial strains at $10^{8} \mathrm{cfu} / \mathrm{ml}$. At $15 \mathrm{~h}$ postinoculation, leaf disks ( $0.5 \mathrm{~cm}$ diameter) were excised and placed into wells of 96-well plates pre-supplied with $100 \mathrm{ml}$ of sterile 
A

SBW25

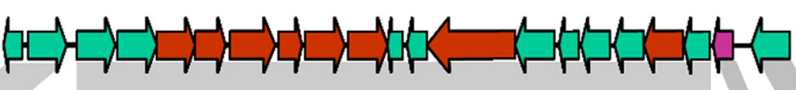

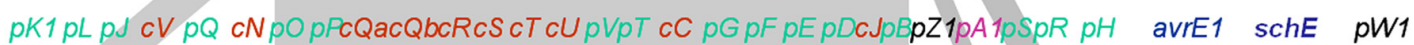

B

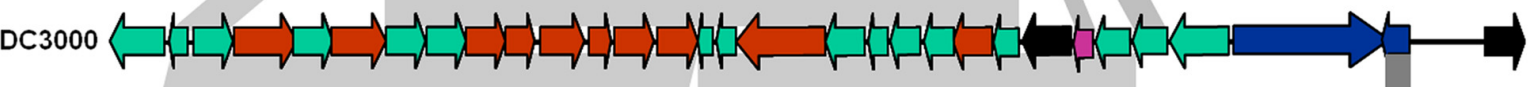

C $2 \mathrm{P} 24$

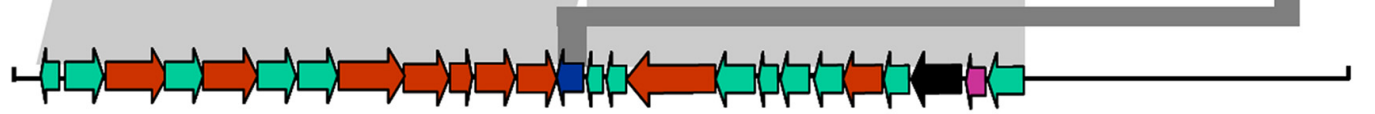

D

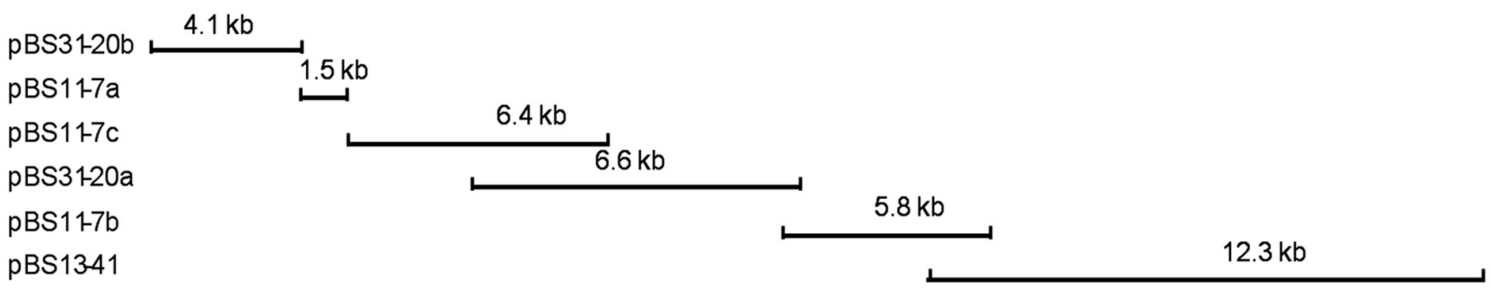

FIGURE 1 | Genetic organization of the rsp/rsc gene cluster of $P$. fluorescens 2P24 (C) and comparison with the hrp/hrc gene clusters of

$\boldsymbol{P}$. fluorescens SBW25 (A) and $\boldsymbol{P}$. syringae pv. tomato DC3000 (B). Predicted open reading frames and their orientation are shown by large arrows. Conserved rsc/hrc genes are shown as red arrows, conserved rsp/hrp genes as green arrows, and harpin proteins as black arrows. Additional ORFs are shown as blue arrows. Homologous genes are connected with gray shading. Full gene names within $r s c / r s p$ and hrc/hrp clusters were shortened and are indicated by a single letter preceded by "c" or "p". (D) The cloning procedures and subclones contain rsp/rsc gene fragments. For details, see Tables $\mathbf{1}$ and $\mathbf{2}$.

water, and then $100 \mathrm{ml}$ of $0.5 \mathrm{mM} \mathrm{L-012} \mathrm{(Wako,} \mathrm{Japan)} \mathrm{in}$ $10 \mathrm{mM}$ morpholinepropanesulfonic acid-KOH buffer ( $\mathrm{pH} 7.4$ ) was added. The intensity of ROS generation was determined according to Oh et al. (2010).

\section{Challenge-Inoculation HR and Assays for Bacterial Colony Development}

The fresh $P$. fluorescens bacterial cells in $10 \mathrm{mM} \mathrm{MgCl}_{2}$ were infiltrated on $N$. benthamiana leaves at $10^{8} \mathrm{cfu} / \mathrm{ml}$. P. syringae DC3000 was challenge-inoculated $6 \mathrm{~h}$ later at $10^{7} \mathrm{cfu} / \mathrm{ml}$ to overlap partially with the $P$. fluorescens pretreated area. After $48 \mathrm{~h}$, leaves were photographed. To observe the suppression of inhibition of the growth of the challenge-inoculated virulent pathogen, the $P$. fluorescens strains were inoculated at $10^{8} \mathrm{cfu} / \mathrm{ml}$ into N. benthamiana, then $6 \mathrm{~h}$ later, P. syringae DC3000 $\Delta$ hopQ1 was challenge-inoculated at $10^{5} \mathrm{cfu} / \mathrm{ml}$ on the edge of the pre-infiltrated area to produce an overlapped area and a non-overlapped area. Bacterial populations of $P$. syringae DC3000 $\triangle$ hopQ1 in the overlapped area were assessed at 0 and 4 days post-inoculation. Each experiment was repeated three times.

\section{RESULTS}

\section{Cloning and Sequence Analysis of the $P$. fluorescens 2P24 T3SS Gene Cluster}

Three cosmid clones, pN11-7, pN13-41, and pN31-20 were isolated from a genomic library of $P$. fluorescens 2P24 using primers P1280 (5' -AACCAGCCGGCKGTSATGA-3') and P1680
(5'-AGGATGAAGACSCGYTCGCG-3') designed from $h r c C$ homologs. Subsequent mapping and sequencing of the subclones of these cosmids delimited a $30 \mathrm{~kb}$ cluster of TTSS-related genes (Figure 1). A total of 25 predicted open reading frames (ORFs) were identified and assigned the gene names rsp (rhizosphereexpressed secretion gene) and $r s c$ ( $r s p$ conserved) according to the non-pathogenic Pseudomonas T3SS convention published previously (Preston et al., 2001; Mavrodi et al., 2011).

The arrangement and orientation of the $P$. fluorescens 2P24 T3SS gene cluster bore a strong similarity to that of $P$. syringae, which has been studied extensively (Huang et al., 1988). It was reported that the hrp genes encoding the TTSS machinery in $P$. syringae are the conserved center region (CCR) of a tripartite pathogenicity island that includes exchangeable (EEL) and conserved (CEL) effector loci (Alfano et al., 2000). We did not find any corresponding EEL and CEL loci from the limited sequences of both sides of the 2P24 T3SS cluster. Specifically, we observed that the ORFs that flanked a $9.0 \mathrm{~kb}$ upstream region of the hrpS gene are similar to proteins unlikely to be linked to type III secretion (Figure 1A). The presence of T3SS-like genes has been reported recently in a few non-pathogenic fluorescent pseudomonads (Preston et al., 2001; Rezzonico et al., 2004; Mavrodi et al., 2011), in which T3SS-like genes of $P$. fluorescens Q8r1-96 share the greatest similarity with strain 2P24 (Table 2). Overall, it appears that T3SS of strain 2P24 has six principal features:

(i) A protein showing $31 \%$ identity to HrpZ1 harpin, which resides between $\operatorname{HrpA} 1$ and $\mathrm{HrpB}$ in the hrpJ operon of $P$. syringae DC3000, was identified from the same 
TABLE 2 | Comparison of $r s p / r s c$ and $h r p / h r c$ cluster proteins in $P$. fluorescens and $P$. syringae.

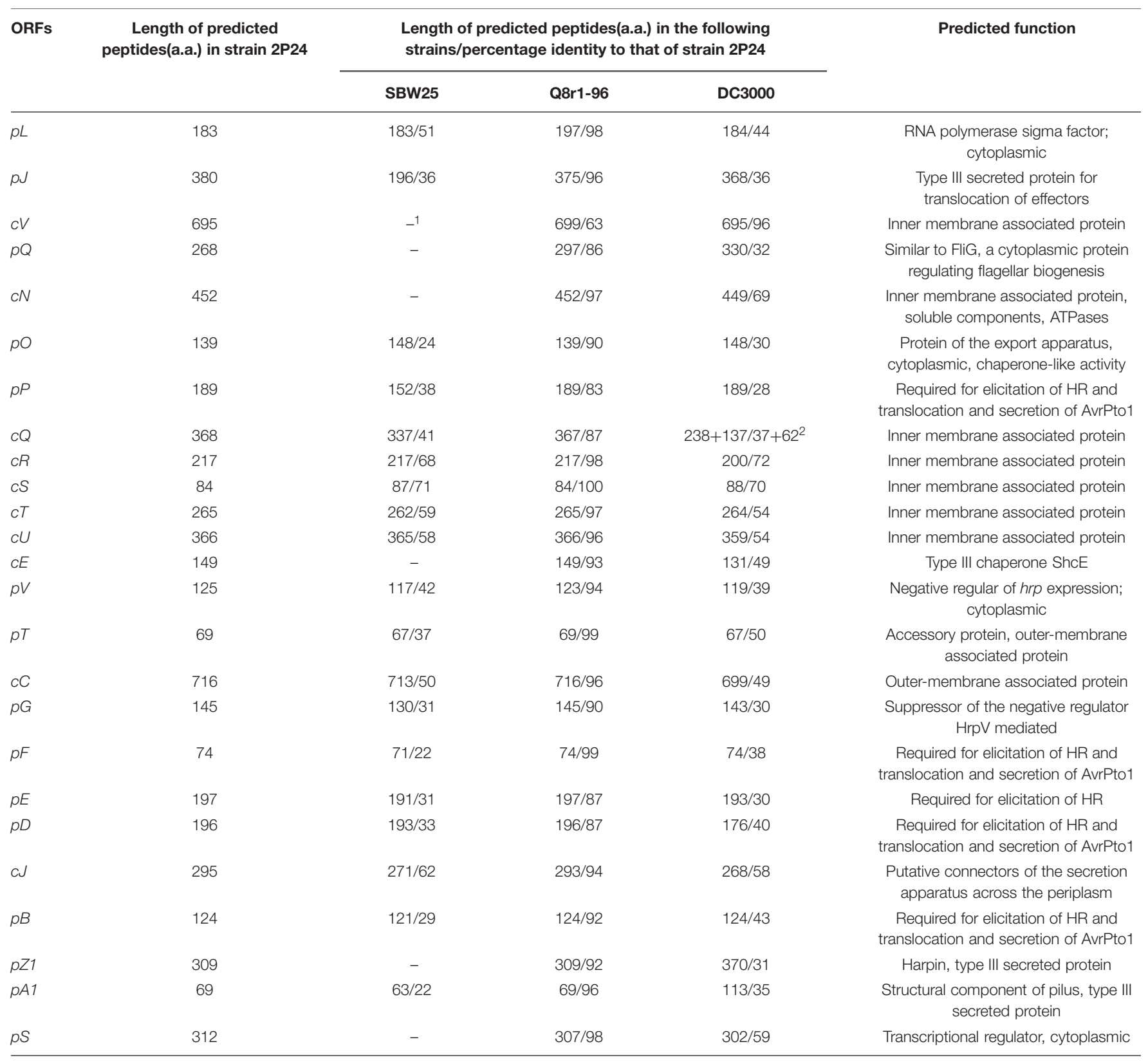

${ }^{1}$ The dashes show that there are no homologs present in P. fluorescens SBW25.

${ }^{2}$ The hrcQ gene is segmented into two genes, hrcQa and hrcQb, in $P$. syringae.

SBW25, P. fluorescens SBW25; Q8r1-96, P. fluorescens Q8r1-96; DC3000, P. syringae pv. tomato DC3000.

position in P. fluorescens 2P24. A HrpZ1 homolog was found also in Q8r1-96, which is another non-pathogenic P. fluorescens (Mavrodi et al., 2011); it was not found in P. fluorescens SBW25 (Preston et al., 2001) or P. fluorescens F113 (Redondo-Nieto et al., 2013), which are well-known PGPR

(ii) In strain $2 \mathrm{P} 24$, a homolog of the $\mathrm{SchE}$ protein is present between $\mathrm{HrpV}$ and $\mathrm{HrcU}$, but neither insertion sequences nor duplicated regions were detected around the flanking sequences of the $s c h E$ gene. (iii) The P. fluorescens $2 \mathrm{P} 24$ cluster carries an intact $h r p V$ operon ( $h r p J, h r c V, h r p Q, h r c N$ ), which is significantly absent from P. fluorescens SBW25, but is very important for secretion of T3SS substrates in phytopathogenic Pseudomonas (Huang et al., 1988; Alfano and Collmer, 1997).

(iv) The $P$. fluorescens $2 \mathrm{P} 24$ cluster harbors only a single response regulator homolog, rspS, which is one of the two regulators ( $h r p S$ and $h r p R$ ) that are 64\% identical to that in P. syringae DC3000 (Grimm et al., 1995; Deng et al., 1998); this is the same homolog that is found in P. fluorescens Q8r1-96 
A

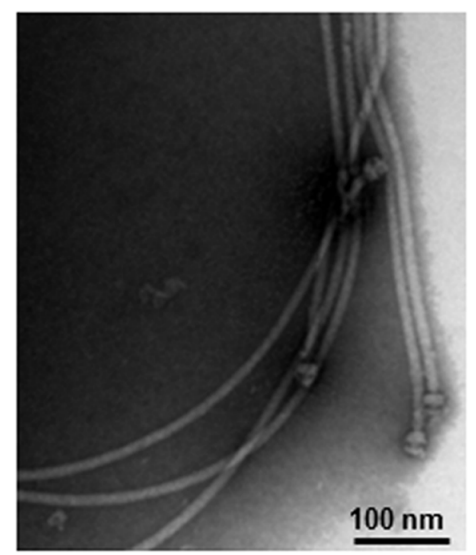

c

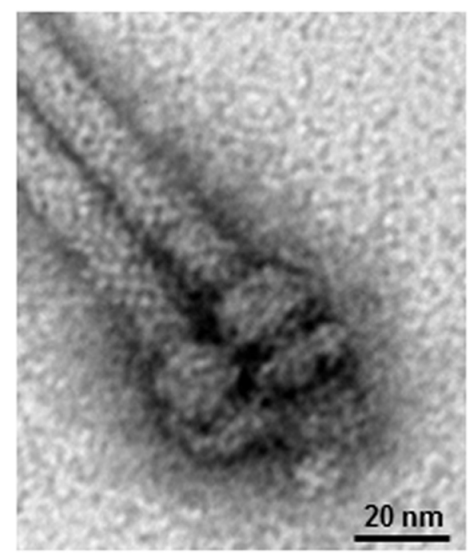

B

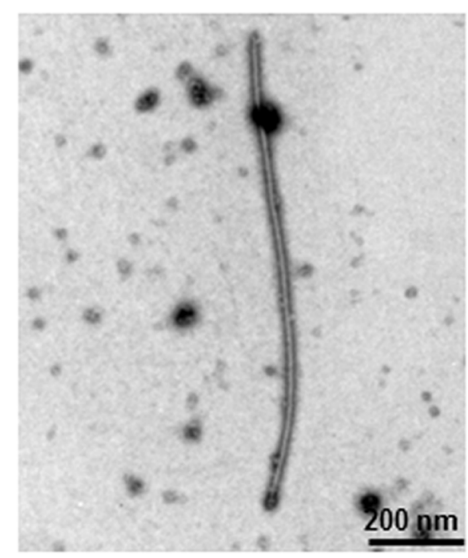

D

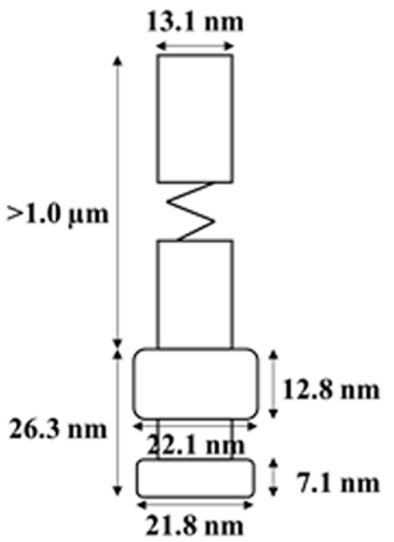

FIGURE 2 | Electron micrograph of purified type III secretion complexes from $\boldsymbol{P}$. fluorescens $\mathbf{2}$ P24. (A,B,C) Purified type III secretion complexes at different magnifications. The sample was obtained from the lower fraction of a $30 \% \mathrm{CsCl}$ gradient centrifugation and observed by TEM. Scale bars as indicated in the images. (D) Proposed size of the type III secretion complex of P. fluorescens 2P24. The size of each portion was measured based on the 20 best preserved type III secretion complexes.

(Mavrodi et al., 2011), but different than the homolog found in P. fluorescens SBW25 (Preston et al., 2001).

(v) In strain $2 \mathrm{P} 24, h r c Q$ is an integrated gene, but it is segmented into two genes, $h r c Q a$ and $h r c Q b$, in P. fluorescens SBW25 (Preston et al., 2001) and P. syringae (Huang et al., 1988).

(vi) Strain 2P24 has all nine hrc homologs, which show 58.6\% identity to that of phytopathogenic bacteria, but $h r p$ homologs show $37.7 \%$ identity. This result indicated that the T3SS component genes are more conserved than the genes that are associated with HR and pathogenicity.

\section{Isolation of T3SS Supramolecular Machinery from P. fluorescens 2P24}

To identify the $P$. fluorescens type III secretion machinery, we attempted to extract the pilus-like structures from strain 2P24 by a modified method. To prevent the interference of flagella and to facilitate isolation of the T3SS machinery, we first made a non-flagellated mutant by knocking out the $f l i C$ gene and, therefore, eliminated their swimming ability on the agar plates (Supplementary Figure S1). The fliC mutant of strain 2P24 grew to log phase and were shocked osmotically and purified further by $30 \%(\mathrm{~W} / \mathrm{V}) \mathrm{CsCl}$ density gradient centrifugation. The components of the type III machinery were pelleted by ultracentrifugation, and their structure and morphological features were examined by TEM. The secretion machinery exhibited a pilus-like structure with cylindrical symmetry (Figure 2). Individual components of the machinery that were enlarged on electron micrographs indicated that the basal part was comprised of two rings. To estimate the size of each portion, 20 purified type III complexes were measured by TEM. The pilus appendages were curved and they fragmented easily during sampling as reported by Roine et al. (1997) for $P$. syringae. Therefore, the length of the pilus could not be measured accurately. But it would longer than $1 \mu \mathrm{m}$ and its diameter was approximately $13.1 \mathrm{~nm}$. The length of the basal portion was $26.3 \mathrm{~nm}$. The upper rings were estimated to be $22.1 \mathrm{~nm}$ in diameter and $12.8 \mathrm{~nm}$ in thickness. The lower rings were similar in diameter to the upper rings, but they were half as thick as the upper rings. To our knowledge, this is the first report that documents the proposed supramolecular structure of the type III T3SS secretion machinery for $P$. fluorescens (Figure 2D). 


\section{$P$. fluorescens 2P24 Elicits HR in Tobacco Leaves with the Help of Cosmid pCPP2274, but not pLN18}

$P$. fluorescens 2P24 does not elicit a HR or any pathogenic symptom when infiltrated into a range of plant leaves such as tobacco, tomato, soybean, rice, and Arabidopsis thaliana at inoculum levels up to $10^{8} \mathrm{cfu} / \mathrm{ml}$. No significant increase in bacterial population levels was observed in 7 days after infiltration of $P$. fluorescens 2P24 into plant leaves (Wei et al., 2004a). To determine the potential function of the T3SS components in P. fluorescens 2P24, a T3SS cosmid named pHIR11 and its derivatives were used to combine with strain 2P24. P. fluorescens 2P24 that carried the hrp/hrc cluster of $P$. syringae pv. syringae 61 on the cosmid pHIR11 elicited an HR in tobacco at $10^{8} \mathrm{cfu} / \mathrm{ml}$, as was observed for P. fluorescens Pf0-1, which is a non-T3SS Pseudomonas strain that was used as a control strain (Compeau et al., 1988), (Figure 3). The strain of $P$. fluorescens 2P24 that carried pLN18, a derivative of pHIR11 with an insertion mutation in the avirulent hopA1 gene (Huang et al., 1991), was unable to elicit a $\mathrm{HR}$, as observed for $P$. fluorescens Pf0-1. This indicated that there is no HopA1 homolog in $P$. fluorescens 2P24 similar to that in strain Pf0-1. However, pCPP2274, a derivative of pHIR11 with a mutation in the hrpZ1 gene, enabled strain 2P24, but not Pf0-1, to elicit a strong HR in tobacco leaves. Therefore, we postulate that the HrpZ1 homolog, RspZ1 of strain 2P24, would complement a harpin deficiency in pCPP2274. We then made a rspZ1 mutant of strain 2P24, 2P24 $\triangle \mathrm{Z} 1$, and introduced pCPP2274 into this mutant. As expected, 2P24 $\triangle \mathrm{Z} 1$ with pCPP2274 failed to trigger $\mathrm{HR}$ in tobacco, and a plasmid-born rspZ1 in $\mathrm{Pf0}$ 1(pCPP2274) recovered HR (Figure 3). This indicated that RspZ1 of $P$. fluorescens $2 \mathrm{P} 24$ has the same function as HrpZ1 in plant pathogens.

\section{Partially Purified RspZ1 from Strain 2P24 Can Elicit Cell Death in Tobacco Leaves}

It is known that the primary property of harpins is their ability to elicit cell death when infiltrated into tobacco leaf intercellular spaces. To test for cell death elicitation, possibility by RspZ1, which is a new harpin candidate in this work, we produced RspZ1 of strain $2 \mathrm{P} 24$ from E. coli cells carrying an appropriate derivative of pET-22b (Supplementary Figure S2). Here, HrpZ1 from P. syringae DC3000 was employed as a positive control. Like HrpZ1, RspZ1 was soluble after overexpression in E. coli. Each protein at $100 \mu \mathrm{g} / \mathrm{ml}$ was infiltrated into leaves of tobacco with or without lanthanum chloride, an inhibitor of harpin-induced cell death ( $\mathrm{He}$ et al., 1993; Kvitko et al., 2007). Surprisingly, RspZ1 elicited a lanthanum chloride-inhibitable cell death in tobacco, which was the same as HrpZ1 (Figure 4). An undiluted empty-vector preparation infiltrated into the same leaf as a control could not elicit any visible response. Elicitation of cell death by the application of an exogenous protein indicated that RspZ1from $P$. fluorescens $2 \mathrm{P} 24$ possesses a defining property of harpin proteins.

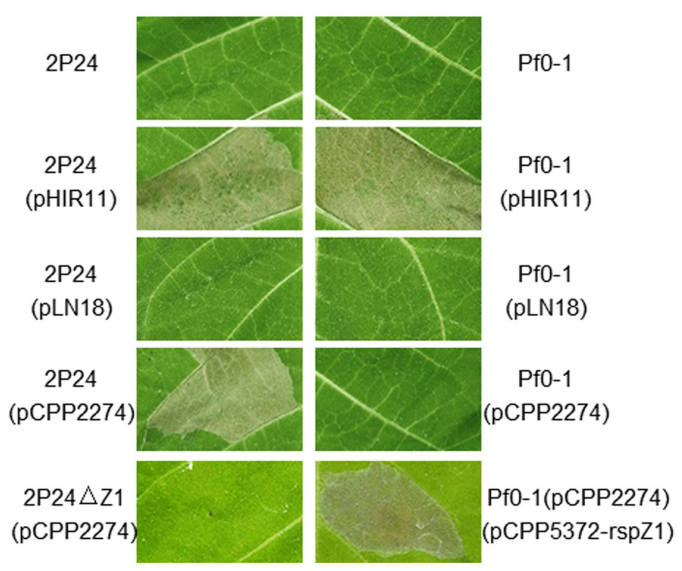

FIGURE 3 | Elicitation of the HR by $P$. fluorescens constitutively expressing pHIR11 and its derivatives. Leaf panels of tobacco (N. tabacum Cv. xanthi) were infiltrated with bacterial suspensions at a concentration of $10^{8} \mathrm{cfu} / \mathrm{ml}$ using a blunt-ended syringe. Cell death was evaluated and representative leaves were photographed $48 \mathrm{~h}$ after inoculation. The experiment was repeated three times with similar results.

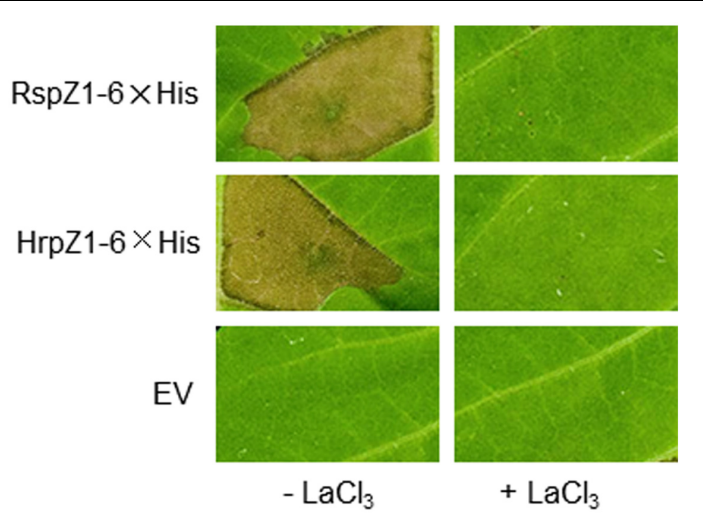

FIGURE 4 | Partially purified harpins RspZ1 (from $P$. fluorescens 2P24) and HrpZ1 (from $P$. syringae pv. tomato DC3000) elicit HR-like tissue collapse in tobacco leaves. $6 \times$ His-tagged recombinant protein preparations were diluted in MES buffer and infiltrated into panels of tobacco leaves with or without $2 \mathrm{mM}$ lanthanum chloride, an inhibitor of HR. The presence or absence of confluent cell death was evaluated $24 \mathrm{~h}$ post-infiltration. A mock, undiluted, empty-vector (EV) preparation was always tested in parallel. The experiment was repeated twice with similar results.

\section{The T3SS of $P$. fluorescens 2P24 Retains Ability to Secrete Effectors, but Loses the Effector Translocation Trait}

T3SSs are complex macromolecular machines that span both the bacterial cell envelope and host cell barriers. The basic property of T3SS is to secrete and deliver proteins, commonly termed effectors, from the bacterial cytoplasm into the host cytoplasm (Alfano and Collmer, 1997; Xin and He, 2013). To determine whether the T3SS of strain 2P24 has the natural traits of T3SS, we used hemagglutinin (HA) immunoblot analysis and an CyaA injection assay to test HopQ1 secretion and translocation in 
A

Pf0-1

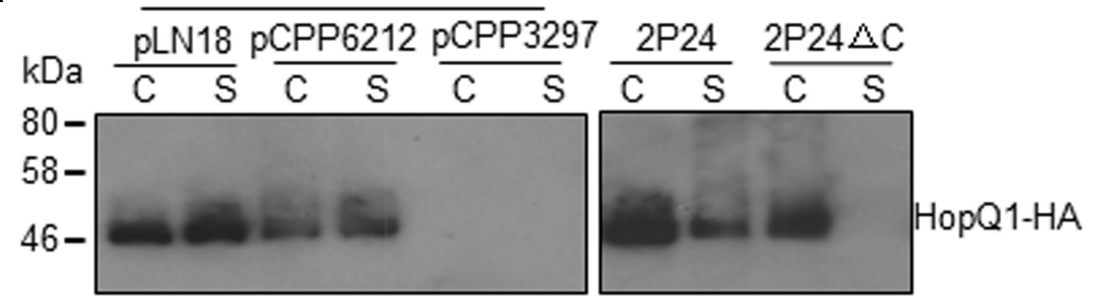

B

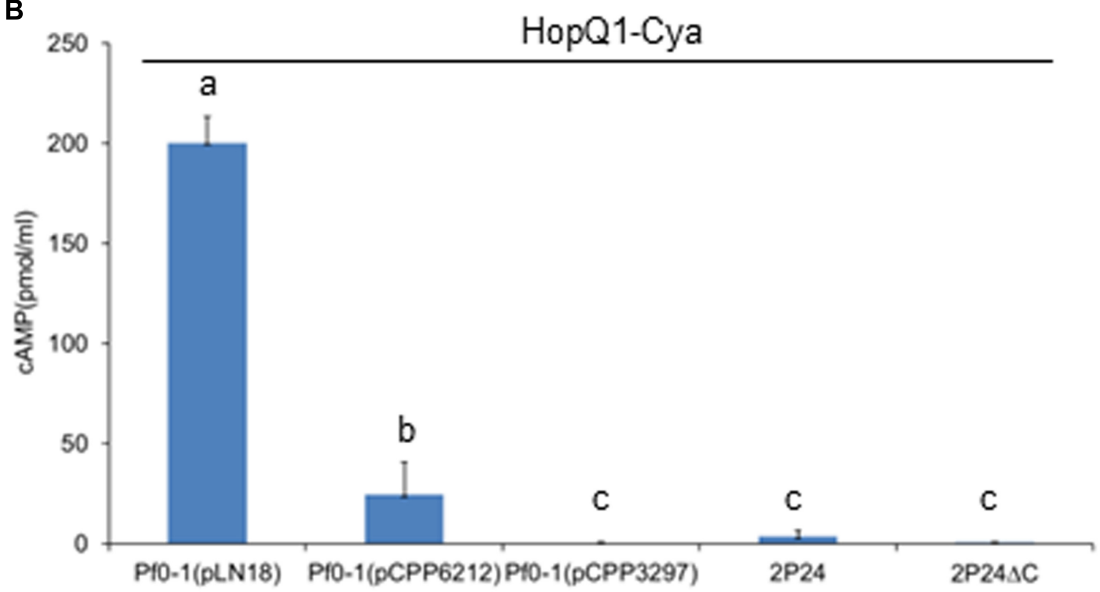

C

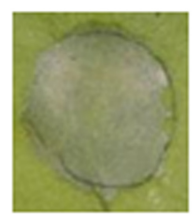

Pf0-1

(pLN18) +HopQ1

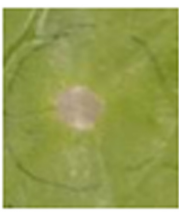

PfO-1

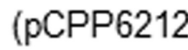
+HopQ1

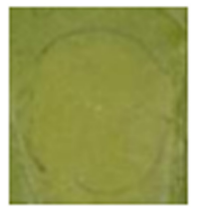

Pf0-1 (pCPP3297) +HopQ1

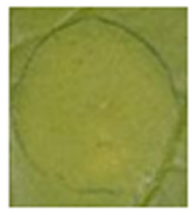

$2 \mathrm{P} 24$

+ HopQ1

FIGURE 5 | P. fluorescens 2P24 has a T3SS-dependent secretion+/translocation- capacity. (A) HopQ1-HA secretion assay. Strains transformed with pCPP5372-hopQ1 were grown from an $\mathrm{OD}_{600}$ of 0.3 to an $\mathrm{OD}_{600}$ of 0.5 . Cell pellet (C) and supernatant (S) fractions were separated by centrifugation. Fractions were analyzed by SDS-PAGE, followed by immunoblotting with anti-HA antibodies. (B) HopQ1-CyaA translocation into N. benthamiana. Strains transformed with pCPP5371-hopQ1 were infiltrated into panels of $N$. benthamiana leaves at $10^{8} \mathrm{cfu} / \mathrm{ml} .1 .0 \mathrm{~cm}$ leaf disks were collected at $12 \mathrm{~h}$ post-inoculation. Effector translocation assays, based on CAMP production by the HopQ1-CyaA reporter, were performed in triplicate on disks from independent leaves. Means shown with the same letters are not different statistically at the 5\% confidence level on the basis of Duncan's multiple range test. (C) Strain 2P24 expressing HopQ1 in $N$. benthamiana does not elicit tissue collapse in accordance with the failure of translocation in 2P24. The bacteria carrying pCPP5372-hopQ1 were infiltrated as described above. Cell death was evaluated and representative leaves were photographed $48 \mathrm{~h}$ after inoculation. The experiment was repeated three times with similar results.

2P24. We introduced constructs carrying HopQ1, an avirulence determinant of $P$. syringae DC3000 in N. benthamiana (Wei et al., 2007), into 2P24, 2P24 $\Delta \mathrm{C}, \mathrm{Pf} 0-1$, and its derivatives. The strains were grown overnight in $\mathrm{KB}$ broth, and cell-bound and supernatant fractions were subjected to Western blot. HopQ1HA was detected in supernatant fractions from wild type 2P24, but not from the 2P24 rscC mutant (Figure 5A). Meanwhile, HopQ1-HA was detected also in supernatant fractions from Pf01with pLN18 and pCPP6212 (Oh et al., 2010), which is a pLN18 derivative missing $h r p K 1$ and a key translocator encoding gene; HopQ1-HA was not detected from Pf0-1 with pCPP3297, a
pLN18 hrcC mutant defective in type III secretion (Figure 5A). These results indicated that effector proteins are secreted in culture through $P$. fluorescens T3SS.

We then infiltrated the strains harboring HopQ1-CyaA into $N$. benthamiana leaves and determined cAMP levels, a product of the CyaA-catalyzed reaction, and cell deaths 12 and $48 \mathrm{~h}$ later, respectively. Plant tissue inoculated with $P$. fluorescens Pf0-1(pLN18)-expressing HopQ1-CyaA showed high levels of cAMP and strong HR, but we detected a sharply lower level of cAMP from the leaves with P. fluorescens Pf0-1(pCPP6212)expressing HopQ1-CyaA, and no cAMP was detected from the 
leaves with $P$. fluorescens Pf0-1(pCPP3297)-expressing HopQ1CyaA (Figure 5B). Accordingly, HopQ1-CyaA expressed in $P$. fluorescens Pf0-1(pLN18), but not in P. fluorescens Pf01(pCPP3297), triggered very strong cell death (Figure 5C). P. fluorescens Pf0-1(pCPP6212)-expressing HopQ1-CyaA elicited a weak cell death, because of the missing key translocator HopK1 (Figure 5C). However, we did not detect cAMP and cell death from plant tissue where HopQ1-CyaA was expressed in wild type 2P24 and 2P24 $\Delta$ C (Figures 5B,C). Taken together, the results demonstrated that HopQ1 was injected into plant leaf cells by $P$. syringae, but not by $P$. fluorescens T3SS.

\section{The T3SS Mutation has no Changes on Biocontrol Capacity of Strain 2P24}

The $r s c C$ mutant strain was tested in vitro for possible phenotypic changes in traits that contribute to biocontrol by $P$. fluorescens $2 \mathrm{P} 24$. The mutant was compared to the parental strain $2 \mathrm{P} 24$ for the ability to produce secondary metabolites, such as the antibiotic 2,4-DAPG, HCN, exoprotease, and siderophores. Unfortunately, no phenotypic changes were found from the $r s c C$ mutant in any of the aforementioned tests (data not shown). The mutant strain was tested also for the ability to antagonize the plant pathogens Rhizoctonia solani and Ralstonia solanacearum. The results indicated that inactivation of the T3SS did not reduce the antagonistic ability of strain $2 \mathrm{P} 24$ against plant pathogens (Supplementary Table S1). The further biocontrol assays on tomato bacterial wilt disease also showed that the T3SS mutation did not result in a reduction in the biocontrol activity of strain 2P24 (Supplementary Table S2).

\section{Strain 2P24 can Trigger Strong Functional MTI that is not Associated with T3SS}

Pseudomonas fluorescens 2P24 is a soil-born PGPR that is present normally in the rhizosphere. We did not know if it could trigger local MTI when inoculated in plant leaves or whether the T3SS had some effect on potential MTI. We then used established assays to determine the extent that 2P24 and 2P24 $\Delta \mathrm{C}$ trigger ROS production, suppress $P$. syringae DC3000 HR and DC3000 4 hopQ1 disease as reported previously (Wei et al., 2013). Strain 2P24 triggered high levels of ROS production that might be induced by the flagellin because the fliC mutant of 2P24 failed to trigger ROS (Figure 6A), which is consistent with a previous report (Wei et al., 2013). Strain 2P24 also exhibited strong suppression of $\mathrm{HR}$ triggered by $P$. syringae DC3000 and pathogen growth of $P$. syringae DC3000 $\Delta$ hopQ1 in $N$. benthamiana (Figures 6B,C). However, the deficiency of the T3SS did not impact functional MTI elicited by 2P24 in any of these tests (Figure 6).

\section{DISCUSSION}

Most of the P. fluorescens bacteria are natural inhabitants of plant roots and soil. An increasing number of $P$. fluorescens strains are being studied due to their ability to produce secondary

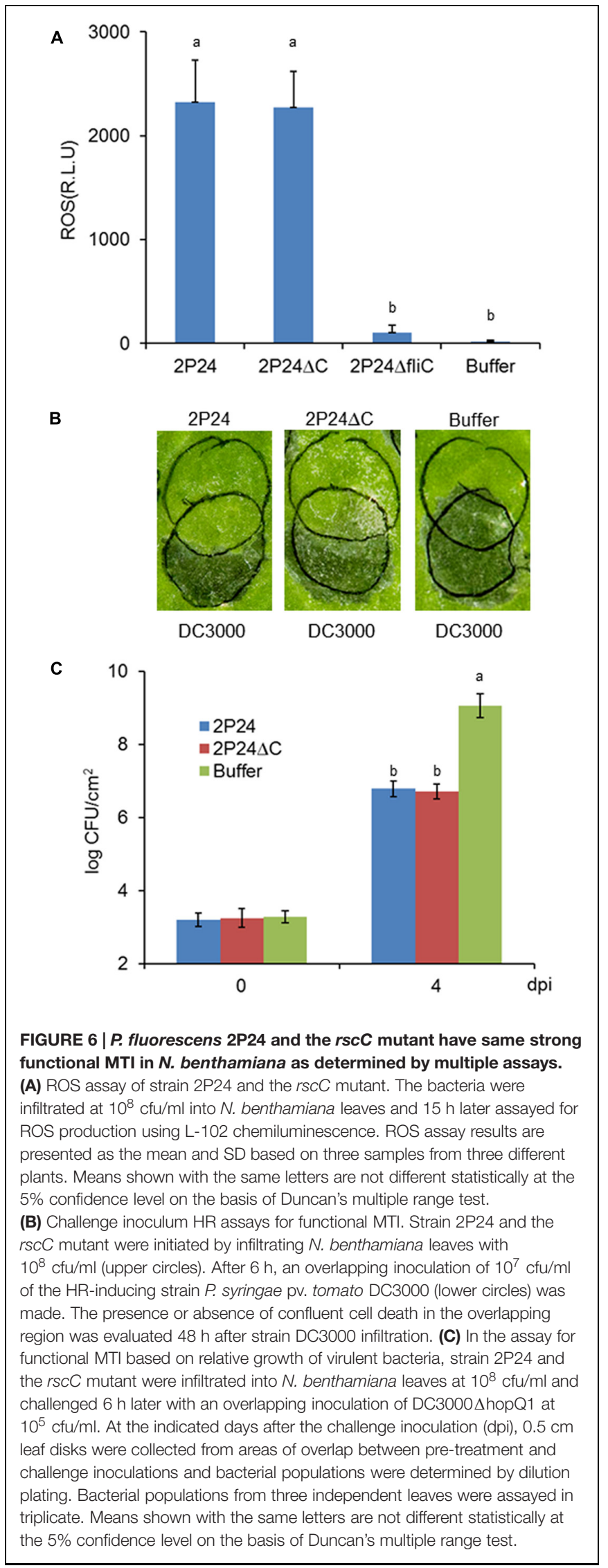


metabolites, such as antibiotics, volatile compounds, $\mathrm{HCN}$, siderophores, cell wall degrading enzymes, and phytohormones (Majumder et al., 2014). As part of our research into the genetic basis for biocontrol capacity of $P$. fluorescens strain 2P24, we isolated and identified a gene cluster that encoded a typical T3SS from the genomic library. The T3SS gene cluster of $P$. fluorescens $2 \mathrm{P} 24, r s p / r s c$, showed greatest similarity to the $h r p / h r c$ pathogenicity island of $P$. syringae, both at the level of genomic organization and amino acid sequence. The $r s p / r s c$ cluster contained all of the nine conserved $h r c$ genes and the hrpA1 gene, which composes the basal body and pilus of the T3SS in plant pathogens (Tampakaki et al., 2004). The same composition and organization of T3SS genes were found also from P. fluorescens Q8r1-96 (Mavrodi et al., 2011). And yet, P. fluorescens Q8r1-96 and 2P24 have the most intact T3SS components compared to other $P$. fluorescens strains.

Although the T3SS in $P$. fluorescens has been studied for many years, its supramolecular structure is still obscure. The presence of $h r p A 1$ and all $h r c$ homologs lends support to the proposition that T3SS machinery is produced in $P$. fluorescens 2P24. In this study, we modified the procedures and then isolated and visualized successfully the T3SS complexes from strain 2P24 for the first time after many attempts. Because $P$. fluorescens 2P24 also produces flagella, which is another kind of surface appendage that is very difficult to distinguish from the T3SS pilus when detached from bacteria, we created and used a $\mathrm{fliC}$ mutant that does not produce flagellin and forfeits swimming ability, under the guidance of similar reports on $P$. syrinage and Salmonella typhimurium (Kubori et al., 1998; Hu et al., 2001). The secretion machinery of P. fluorescens 2P24 exhibited a piluslike structure similar to that of $P$. syringae that is composed of an elongated pilus and a cylindrical basal body (Hu et al., 2001). The successful isolation and identification of T3SS machinery from $P$. fluorescens $2 \mathrm{P} 24$ confirms the integrity of $r s p / r s c$ genes in the genomic organization. Unlike the isolation condition for T3SS complex from plant pathogen P. syringae (Roine et al., 1997), we only were able to isolate the T3SS complex from $\mathrm{KB}$ rich medium, but not from the $h r p$-inducing medium. This might suggest that the T3SS in P. fluorescens 2P24 is not a strict pathogenic hrpinduced system, which is consistent with the presence of PGPR in the rhizosphere but not the leaf ecosystems.

Bacterial T3SS is of special interest because, by utilizing this system, bacteria are able to inject bacterial effector proteins directly into host cells. The typical process includes crossing the bacterial membranes termed secretion and the step of crossing the host membranes being called translocation (Alfano and Collmer, 2004). The cosmid pLN18 that contains a functional cluster of $h r p / h r c$ T3SS genes from $P$. syringae, which is expressed in $P$. fluorescens, is sufficient to deliver effector proteins into plant cells (Huang et al., 1988). To test the functionality of $P$. fluorescens 2P24 T3SS, we introduced HopQ1 from $P$. syringae into $P$. fluorescens $2 \mathrm{P} 24$ and $\mathrm{PfO}-1$ (pLN18) and tried to observe a HopQ1-dependent HR in leaves of $N$. benthamiana. However, we did not find expected HR from 2P24-expressing HopQ1, but we did find HR from $P$. fluorescens Pf0-1(pLN18)-expressing HopQ1. An immunoblot analysis showed that HopQ1-HA was secreted successfully through the T3SS by strain 2P24 that was dependent on the $r s c C$ gene present. But the HopQ1-CyaA translocation assay demonstrated that strain 2P24 failed to inject HopQ1-CyaA into plant cells, although a high level of HopQ1CyaA proteins was detected from plant leaves expressed by P. fluorescens Pf0-1(pLN18). Further determination suggested the HopQ1-dependent HR expressed by P. fluorescens Pf0-1(pLN18) was patently dependent on $\operatorname{HrpK1}$, which is a major translocator of bacterial T3SS, and which is absent from strain 2P24. Although the most similar T3SS in P. fluorescens Q8r1-96 was reported to translocate Rop effectors into tobacco leaves, the level of effector proteins was 100-fold lower than that expressed by $P$. fluorescens 55(pLN1965) (Mavrodi et al., 2011). It is very difficult to postulate that such translocation capacity by $P$. fluorescens Q8r196 is sufficient to trigger strong effector-dependent phenotypes like HR. Mavrodi et al. (2011) showed that the three Q8r196 Rop effectors expressed in P. fluorescens 55(pHIR11) and $P$. fluorescens 55(pLN1965) were capable of suppressing HopA1dependent HR and flg22-dependent ROS production. It should be noted that these capabilities were based on high translocation levels of pHIR11and (pLN1965) in P. fluorescens 55, but not in the native T3SS of $P$. fluorescens Q8r1-96 (Mavrodi et al., 2011). Although the genome of strain 2P24 has not been sequenced and we do not know if 2P24 really has effector homologs, the fact that wild type $2 \mathrm{P} 24$ and the $r s c \mathrm{C}$ mutant triggered the same high level of ROS production suggested that no significant T3SS-dependent MTI suppressor was present in strain 2P24. We also found that 2P24-expressing HopQ1 did not reduce the ROS level of wild type 2P24 (Supplementary Figure S3), which indicated also that HopQ1 was not translocated into plant cells through the T3SS of strain $2 \mathrm{P} 24$.

Besides effectors, other proteins like harpins secreted by T3SS play a critical role in microbe-host interactions. Harpins are universal components of plant pathogen T3SSs, which can elicit innate immunity when applied exogenously to plant cells (He et al., 1993; Kvitko et al., 2007). In P. syringae DC3000, four harpin proteins, HrpZ1, HrpW1, HopAK1, and HopP1, triggered cell death in tobacco with the purified proteins and they were involved also in effector translocation (Kvitko et al., 2007). The DNA sequence of the $P$. fluorescens 2P24 rsp/rsc cluster revealed the presence of a harpin-like encoding gene $r s p Z 1$. The purified RspZ1 protein elicited cell death in tobacco as do the usual harpin proteins. And rspZ1 also complemented the mutation of $h r p Z 1$ from pHIR11 to translocate HopA1 and trigger cell death in tobacco. To date, in all of T3SS ${ }^{+}$PGPR, only P. fluorescens Q8r196 was reported as having a RspZ1 homolog in the $r s p / r s c$ cluster, whereas the functionality of it has not been determined (Mavrodi et al., 2011). Although our work could not define HrpZ1 as the sole harpin and translocator in strain 2P24, our results show for the first time that the cell death-like innate immunity triggered by RspZ1 aids our comprehensive understanding of the induced immunity and resistance by PGPR.

MAMPs are common elicitors in PGPR for basic resistance and induced systemic resistance (ISR) in plants (De Vleesschauwer and Hofte, 2009). Flagellin was investigated as the major MAMPs in pathogenic P. syrinage DC3000 or non-pathogenic P. fluorescens Pf0-1 (Wei et al., 2013). The flagellin-triggered MTI could be suppressed by injection of 
effectors (Wei et al., 2013). In P. fluorescens Q8r1-96, RopM, RopB, and RopAA suppressed both MTI and ETI immune responses, which was contrary to the capacity of Q8r1-96 to induce ISR in Arabidopsis thaliana (Mavrodi et al., 2011). However, strain 2P24 could elicit strong functional MTI and its endogenous TTSS could not deliver effectors to suppress MTI and ETI (Figure 6 and Supplementary Figure S3), which is apparently consistent with the capacity of strain 2P24 to induce resistance in tomato (Wei et al., 2004a). Summarily, our data suggest that $P$. fluorescens 2 P24 is a fantastic PGPR agent, which not only produces important secondary metabolites, but which also elicits strong functional MTI. Although we were unable to identify a role for 2P24 T3SS in biocontrol, it does not mean the T3SS in PGPR has no biological role. As a rhizosphere colonization bacterium, 2P24 is not like phyllosphere-derived pathogens in essence to inject proteins into mesophyll cells and trigger local innate immunity. A plausible explanation is that the T3SS acquirement in PGPR strains might be a consequence of cooption and could play a role in rhizosphere environment adaption and fitness (Jackson et al., 2005). Our ability to isolate the secretion ${ }^{+} /$translocation $^{-}$T3SS machinery clarifies the basic functionality of PGPR T3SS, which should focus our future attention on identifying potential T3SSsecreted proteins that occur during root colonization or cell-cell interactions.

\section{REFERENCES}

Alfano, J. R., Charkowski, A. O., Deng, W. L., Badel, J. L., Petnicki-Ocwieja, T., van Dijk, K., et al. (2000). The Pseudomonas syringae Hrp pathogenicity island has a tripartite mosaic structure composed of a cluster of type III secretion genes bounded by exchangeable effector and conserved effector loci that contribute to parasitic fitness and pathogenicity in plants. Proc. Natl. Acad. Sci. U.S.A. 97, 4856-4861.

Alfano, J. R., and Collmer, A. (1997). The type III (Hrp) secretion pathway of plant pathogenic bacteria: trafficking harpins, Avr proteins, and death. J. Bacteriol. $179,5655-5662$.

Alfano, J. R., and Collmer, A. (2004). Type III secretion system effector proteins: double agents in bacterial disease and plant defense. Annu. Rev. Phytopathol. 42, 385-414. doi: 10.1146/annurev.phyto.42.040103. 110731

Barret, M., Egan, F., Moynihan, J., Morrisey, J. P., Lesouhaitier, O., and O'Gara, F. (2013). Characterisation of the SPI-1 and Rsp type three secretion systems in Pseudomonas fluorescens F113. Environ. Microbiol. Rep. 5, 377-386. doi: 10.1111/1758-2229.12039

Berendsen, R. L., van Verk, M. C., Stringlis, I. A., Zamioudis, C., Tommassen, J., Pieterse, C. M., et al. (2015). Unearthing the genomes of plant-beneficial Pseudomonas model strains WCS358, WCS374 and WCS417. BMC Genomics 16:539. doi: 10.1186/s12864-015-1632-z

Bergeron, J. R. C., Worrall, L. J., Sgourakis, N. G., DiMaio, F., Pfuetzner, R. A., Felise, H. B., et al. (2013). A refined model of the prototypical Salmonella SPI1 T3SS basal body reveals the molecular basis for its assembly. PLoS Pathog. 9:e1003307. doi: 10.1371/journal.ppat.1003307

Buell, C. R., Joardar, V., Lindeberg, M., Selengut, J., Paulsen, I. T., Gwinn, M. L., et al. (2003). The complete genome sequence of the Arabidopsis and tomato pathogen Pseudomonas syringae pv. tomato DC3000. Proc. Natl. Acad. Sci. U.S.A. 100, 10181-10186. doi: 10.1073/pnas.1731982100

Compeau, G., Al-Achi, B. J., Platsouka, E., and Levy, S. B. (1988). Survival of rifampin-resistant mutants of Pseudomonas fluorescens and Pseudomonas putida in soil systems. Appl. Environ. Microbiol. 54, 2432-2438.

De Vleesschauwer, D., and Hofte, M. (2009). Rhizobacteria-induced systemic resistance. Adv. Bot. Res. 51, 223-281. doi: 10.1016/S0065-2296(09)51006-3

\section{AUTHOR CONTRIBUTIONS}

H-LW and XZ designed research; PL, WZ, and H-LW performed research; PL, WZ, L-QZ, and HW analyzed data; H-LW wrote the paper.

\section{FUNDING}

This work was supported by Chinese National Natural Science Foundation (30700538) and National Programs for High Technology Research and Development of China (2011AA10A205).

\section{ACKNOWLEDGMENT}

We are grateful to Professor Thomas A. Gavin, Cornell University, for critical reading and editing of the manuscript.

\section{SUPPLEMENTARY MATERIAL}

The Supplementary Material for this article can be found online at: http://journal.frontiersin.org/article/10.3389/fpls.2015.01190

Deane, J. E., Roversi, P., and Cordes, F. (2006). Molecular model of a type III secretion system needle: implications for host-cell sensing. Proc. Natl. Acad. Sci. U.S.A. 103, 12529-12533. doi: 10.1073/pnas.06026 89103

Deng, W. L., Preston, G., Collmer, A., Chang, C. J., and Huang, H. C. (1998). Characterization of the hrpC and hrpRS operons of Pseudomonas syringae pathovars syringae, tomato, and glycinea and analysis of the ability of hrpF, hrpG, hrcC, hrpT, and hrpV mutants to elicit the hypersensitive response and disease in plants. J. Bacteriol. 180, 4523-4531.

Duan, J., Jiang, W., Cheng, Z., Heikkila, J. J., and Glick, B. R. (2013). The complete genome sequence of the plant growth-promoting bacterium Pseudomonas sp. UW4. PLoS ONE 8:e58640. doi: 10.1371/journal.pone.005 8640

Figurski, D., and Helinski, D. R. (1979). Replication of an origin-containing derivative of plasmid RK2 dependent on a plasmid function provided in trans. Proc. Natl. Acad. Sci. U.S.A. 76, 1648-1652. doi: 10.1073/pnas.76. 4.1648

Fujii, T., Cheung, M., Blanco, A., Kato, T., Blocker, A., and Namba, K. (2012). Structure of a type III secretion needle at 7-A resolution privdes insight into its assembly and signaling mechanisms. Proc. Natl. Acad. Sci. U.S.A. 109, 4461-4466. doi: 10.1073/pnas.1116126109

Galán, J. E., and Collmer, C. (1999). Type III secretion machines: bacterial devices for protein delivery into host cells. Science 284, 1322-1328. doi: 10.1126/science.284.5418.1322

Gopalan, S., Bauer, D. W., Alfano, J. R., Loniello, A. O., He, S. Y., and Collmer, A. (1996). Expression of the Pseudomonas syringae avirulence protein AvrB in plant cells alleviates its dependence on the hypersensitive response and pathogenicity (Hrp) secretion system in eliciting genotypespecific hypersensitive cell death. Plant Cell 8, 1095-1105. doi: 10.2307/ 3870354

Grimm, C., Aufsatz, W., and Panopoulos, N. J. (1995). The hrpRS locus of Pseudomonas syringae pv. phaseolicola constitutes a complex regulatory unit. Mol. Microbiol. 15, 155-165. doi: 10.1111/j.1365-2958.1995.tb02230.x

Hauser, A. R. (2009). The type III secretion system of Pseudomonas aeruginosa: infection by injection. Nat. Rev. Microbiol. 7, 654-665. doi: $10.1038 /$ nrmicro2199 
He, S. Y., Huang, H. C., and Collmer, A. (1993). Pseudomonas syringae pv. syringae harpinPss: a protein that is secreted via the Hrp pathway and elicits the hypersensitive response in plants. Cell 73, 1255-1266. doi: 10.1016/00928674(93)90354-S

Hu, W., Yuan, J., Jin, Q., Hart, P., and He, S. Y. (2001). Immunogold labeling of Hrp pili of Pseudomonas syringae pv. tomato assembled in minimal medium and in planta. Mol. Plant Microbe Interact. 14, 234-241. doi: 10.1094/MPMI.2001.14.2.234

Huang, H. C., Hutcheson, S. W., and Collmer, A. (1991). Characterization of the hrp cluster from Pseudomonas syringae pv. syringae 61 and TnphoA tagging of genes encoding exported or membrane-spanning Hrp proteins. Mol. Plant Microbe Interact. 4, 469-476. doi: 10.1094/MPMI-4-469

Huang, H. C., Schuurink, R., Denny, T. P., Atkinson, M. M., Baker, C. J., Yucel, I., et al. (1988). Molecular cloning of a Pseudomonas syringae pv. syringae gene cluster that enables Pseudomonas fluorescens to elicit the hypersensitive response in tobacco plants. J. Bacteriol. 170, 4748-4756.

Jackson, R. W., Preston, G. M., and Rainey, P. B. (2005). Genetic characterization of Pseudomonas fluorescens SBW25 rsp gene expression in the phytosphere and in vitro. J. Bacteriol. 187, 8477-8488. doi: 10.1128/JB.187.24.8477-8488.2005

Jin, Q., and He, S. Y. (2001). Role if the Hrp pilus in type III protein secretion in Pseudomonas syringae. Science 294, 2556-2558.

Jin, Q., Hu, W., Brown, I., McGhee, G., Hart, P., Jones, A. L., et al. (2001). Visualization of secreted Hrp and Avr proteins along the Hrp pilus during type III secretion in Erwinia amylovora and Pseudomonas syringae. Mol. Microbiol. 40, 1129-1139. doi: 10.1046/j.1365-2958.2001.02455.x

Keen, N. T., Tamaki, S., Kobayashi, D., and Trollinger, D. (1988). Improved broadhost-range plasmids for DNA cloning in Gram-negative bacteria. Gene 70, 191-197. doi: 10.1016/0378-1119(88)90117-5

King, E. O., Ward, M. K., and Raney, D. E. (1954). Two simple media for the demonstration of pyocyanin and fluorescein. J. Lab. Clin. Med. 44, 301-307.

Kubori, T., Matsushima, Y., Nakamura, D., Uralil, J., Lara-Tejero, M., Sukhan, A., et al. (1998). Supramolecular structure of the Salmonella typhimurium type III protein secretion system. Science 280, 602-605. doi: $10.1126 /$ science. 280.5363 .602

Kvitko, B. H., Ramos, A. R., Morello, J. E., Oh, H. S., and Collmer, A. (2007). Identification of harpins in Pseudomonas syringae pv. tomato DC3000, which are functionally similar to HrpK1 in promoting translocation of type III secretion system effectors. J. Bacteriol. 189, 8059-8072. doi: 10.1128/JB. 01146-07

Li, C. M., Brown, I., Mansfield, J., Stevens, C., Boureau, T., Romantschuk, M., et al. (2002). The Hrp pilus of Pseudomonas syringae elongates from its tip and acts as a conduit for translocation of the effector protein HrpZ. EMBO J. 21, 1909-1915. doi: 10.1093/emboj/21.8.1909

Majumder, D., Kingbrailatpam, J. D., Suting, G., Kangjam, B., and Lyngdoh, D. (2014). "Pseudomonas fluorescens: a potential biocontrol agent for management of fungal diseases of crop plants," in Future Challenges in Crop Protection Against Fungal Pathogens, eds A. Goyal and C. Manoharachary (New York, NY: Springer), 317-342.

Mansfield, J., Genin, S., Magori, S., Citovsky, V., Sriariyanum, M., Ronald, P., et al. (2012). Top 10 plant pathogenic bacteria in molecular plant pathology. Mol. Plant Pathol. 13, 614-629. doi: 10.1111/j.1364-3703.2012.00804.x

Mavrodi, D. V., Joe, A., Mavrodi, O. V., Hassan, K. A., Weller, D. M., Paulsen, I. T., et al. (2011). Structural and functional analysis of the type III secretion system from Pseudomonas fluorescens Q8r1-96. J. Bacteriol. 193, 177-189. doi: 10.1128/JB.00895-10

Mazurier, S., Lemunier, M., Siblot, S., Mougel, C., and Lemanceau, P. (2004). Distribution and diversity of type III secretion system-like genes in saprophytic and phytopathogenic fluorescent pseudomonads. FEMS Microbiol. Ecol. 49, 455-467. doi: 10.1016/j.femsec.2004.04.019

Moraes, T. F., Spreter, T., and Strynadka, N. C. (2008). Piecing together the type III injectisome of bacterial pathogens. Curr. Opin. Struct. Biol. 18, 258-266. doi: 10.1016/j.sbi.2007.12.011

Oh, H. S., Kvitko, B. H., Morello, J. E., and Collmer, A. (2007). Pseudomonas syringae lytic transglycosylases co-regulated with the type III secretion system contribute to the translocation of effector proteins into plant cells. J. Bacteriol. 189, 8277-8289. doi: 10.1128/JB.00998-07

Oh, H. S., Park, D. H., and Collmer, A. (2010). Components of the Pseudomonas syringae type III secretion system can suppress and may elicit plant innate immunity. Mol. Plant Microbe Interact. 23, 727-739. doi: 10.1094/MPMI-236-0727

Preston, G. M., Bertrand, N., and Rainey, P. B. (2001). Type III secretion in plant growth-promoting Pseudomonas fluorescens SBW25. Mol. Microbiol. 41, 999-1014. doi: 10.1046/j.1365-2958.2001.02560.x

Redondo-Nieto, M., Barret, M., Morrissey, J., Germaine, K., Martínez-Granero, F., Barahona, E., et al. (2013). Genome sequence reveals that Pseudomonas fluorescens F113 possesses a large and diverse array of systems for rhizosphere function and host interaction. BMC Genomics 14:54. doi: 10.1186/1471-216414-54

Rezzonico, F., Binder, C., Defago, G., and Moenne-Loccoz, Y. (2005). The type III secretion system of biocontrol Pseudomonas fluorescens $\mathrm{KD}$ targets the phytopathogenic Chromista Pythium ultimum and promotes cucumber protection. Mol. Plant Microbe Interact. 18, 991-1001. doi: 10.1094/MPMI18-0991

Rezzonico, F., Defago, G., and Moenne-Locco, Y. (2004). Comparison of ATPase-encoding type III secretion system hrcN genes in biocontrol fluorescent pseudomonads and in phytopathogenic proteobacteria. Appl. Environ. Microbiol. 70, 5119-5131. doi: 10.1128/AEM.70.9.5119-5131.2004

Roine, E., Wei, W., Yuan, J., Nurmiaho-Lassila, E. L., Kalkkinen, N., Romantschuk, M., et al. (1997). Hrp pilus: an hrp-dependent bacterial surface appendage produced by Pseudomonas syringae pv. tomato DC3000. Proc. Natl. Acad. Sci. U.S.A. 94, 3459-3464. doi: 10.1073/pnas.94.7.3459

Sambrook, J., Fritsch, E. F., and Maniatis, T. (1989). Molecular Cloning: A Laboratory Manual, 2nd Edn. Cold Spring Harbor, NY: Cold Spring Harbor Laboratory.

Schraidt, O., and Marlovits, T. (2011). Three-dimensional model of Salmonella's needle complex at subnanometer resolution. Science 331, 1192-1195. doi: $10.1126 /$ science. 1199358

Spreter, T., Yip, C. K., Sanowar, S., Andre, I., Kimbrough, T. G., Deng, M., et al. (2009). A conserved structural motif mediates formation of the periplasmic rings in the type III secretion system. Nat. Struct. Mol. Biol. 16, 468-476. doi: 10.1038/nsmb.1603

Tampakaki, A. P., Fadouloglou, V. E., Gazi, A. D., Panopoulos, N. J., and Kokkinidis, M. (2004). Conserved features of type III secretion. Cell. Microbiol. 6, 805-816. doi: 10.1111/j.1462-5822.2004.00432.x

Viollet, A., Corberand, T., Mougel, C., Robin, A., Lemanceau, P., and Mazurier, S. (2011). Fluorescent pseudomonads harboring type III secretion genes are enriched in the mycorrhizosphere of Medicago truncatula. FEMS Microbiol. Ecol. 75, 457-467. doi: 10.1111/j.1574-6941.2010.01021.x

Wei, C. F., Kvitko, B. H., Shimizu, R., Crabill, E., Alfano, J. R., Lin, N. C., et al. (2007). A Pseudomonas syringae pv. tomato DC3000 mutant lacking the type III effector HopQ1-1 is able to cause disease in the model plant Nicotiana benthamiana. Plant J. 51, 32-46. doi: 10.1111/j.1365-313X.2007.03126.x

Wei, H. L., Chakravarthy, S., Worley, J. N., and Collmer, A. (2013). Consequences of flagellin export through the type III secretion system of Pseudomonas syringae reveal a major difference in the innate immune systems of mammals and the model plant Nicotiana benthamiana. Cell. Microbiol. 15, 601-618. doi: $10.1111 / \mathrm{cmi} .12059$

Wei, H. L., and Collmer, C. (2012). Multiple lessons from the multiple functions of a regulator of type III secretion system assembly in the plant pathogen Pseudomonas syringae. Mol. Microbiol. 85, 195-200. doi: 10.1111/j.13652958.2012.08119.x

Wei, H. L., Wang, Y., Zhang, L. Q., and Tang, W. (2004a). Identification and characterization of biocontrol bacterial strain 2P24 and CPF-10. Acta Phytopathol. Sin. 34, 80-85.

Wei, H. L., Zhou, H. Y., Zhang, L. Q., Wang, Y., and Tang, W. H. (2004b). Experimental evidence on the functional agent of 2,4-diacetylphloroglucinol in biocontrol activity of Pseudomonas fluorescens 2P24. Acta Microbiol. Sin. 44, 663-666.

Wei, H. L., and Zhang, L. Q. (2005). Cloning and functional characterization of the gacS gene of the biocontrol strain Pseudomonas fluorescens 2P24. Acta Microbiol. Sin. 45, 368-372.

Wei, H. L., and Zhang, L. Q. (2006). Quorum-sensing system influences root colonization and biological control ability in Pseudomonas fluorescens 2P24. Antonie van Leeuwenhoek 89, 267-280. doi: 10.1007/s10482-005-9028-8

Xin, X. F., and He, S. Y. (2013). Pseudomonas syringae pv. tomato DC3000: a model pathogen for probing disease susceptibility and hormone signaling 
in plants. Annu. Rev. Phytopathol. 51, 473-498. doi: 10.1146/annurev-phyto082712-102321

Conflict of Interest Statement: The authors declare that the research was conducted in the absence of any commercial or financial relationships that could be construed as a potential conflict of interest.
Copyright $\odot 2016$ Liu, Zhang, Zhang, Liu and Wei. This is an open-access article distributed under the terms of the Creative Commons Attribution License (CC BY).

The use, distribution or reproduction in other forums is permitted, provided the original author(s) or licensor are credited and that the original publication in this journal is cited, in accordance with accepted academic practice. No use, distribution or reproduction is permitted which does not comply with these terms. 